\title{
Model Kepenggunaan-Wasatiyyah Untuk Mengimbangi Fenomena Kepenggunaan Dalam Sistem Ekonomi Liberal- Kapitalis: Satu Sorotan
}

\author{
Mohd Shukri Hanapi (Pengarang Penghubung) \\ Pusat Kajian Pengurusan Pembangunan Islam (ISDEV) \\ Universiti Sains Malaysia, 11800 Pulau Pinang. \\ Tel: +6019-450 7576 E-mel: hshukeri@yahoo.com \\ Siti Mastura Muhammad \\ Pusat Kajian Pengurusan Pembangunan Islam (ISDEV) \\ Universiti Sains Malaysia, 11800 Pulau Pinang. \\ Tel: +6019-497 4123 E-mel: jernihan_hati@yahoo.com
}

\begin{abstract}
Abstrak
Dalam sistem ekonomi liberal-kapitalis yang diguna pakai secara meluas pada ketika ini, seseorang yang membelanjakan pendapatannya bagi tujuan memaksimumkan utiliti material merupakan sesuatu yang rasional dan digalakkan. Hal ini kerana penggunaan utiliti material yang maksimum dijadikan sebagai ukuran kemajuan. Dengan itu, semakin tinggi kepenggunaan utiliti material, semakin tinggilah tahap kemajuan. Walau bagaimanapun, memaksimumkan penggunaan utiliti bagi mencapai kepuasan material sebegini boleh menimbulkan kesan negatif terutamanya masalah keberhutangan yang serius dan muflis. Masalah ini berlaku apabila para pengguna membelanjakan pendapatannya bagi tujuan memaksimumkan kepuasan material melampaui kemampuan. Justeru, mereka terpaksa berhutang. Sebagai umat Islam, bagaimanakah penggunaan yang sepatutnya diamalkan? Apakah ukurannya juga berasaskan kepenggunaan utiliti yang maksimum seperti dalam sistem ekonomi liberal-kapitalis yang banyak diamalkan sekarang ataupun terdapat ukuran yang khusus hingga melahirkan satu bentuk kepenggunaan yang unik? Berhubung isu inilah, makalah ini bertujuan meneliti fenomena kepenggunaan dalam sistem ekonomi liberal-kapitalis dan meneroka satu model kepenggunaan yang lebih berhemah dan terbaik (wasatiyyah).
\end{abstract}

Dalam perkataan lain, ia dikenali sebagai kepenggunaan-wasatiyyah. Bagi mencapai objektif ini, kajian ini hanya melibatkan penerokaan idea berkaitan model kepenggunaanwasatiyyah. Hasilnya ia menemukan model kepenggunaan-wasatiyyah yang berfalsafahkan tauhid, tahap kepenggunaan yang berakar umbikan komponen maqasid al-syari'ah dan bermatlamatkan mencapai keredaan Allah SWT.

Kata Kunci: kepenggunaan, wasatiyyah, fenomena, ekonomi, liberal-kapitalis

\section{Pengenalan}

Salah satu elemen penting dalam kegiatan ekonomi adalah penggunaan. Dalam hierarki barangan dan perkhidmatan, penggunaan merupakan peringkat terakhir setelah selesai proses pengeluaran dan pengagihan. Tanpa penggunaan, proses pengeluaran tidak mungkin akan dilakukan (Fadhilah Mat Nor, et. al., 2016). Lazimnya, perbincangan mengenai penggunaan dalam ilmu ekonomi konvensional akan merangkumi topik-topik seperti matlamat penggunaan, andaian penggunaan, konsep rasionaliti dan utiliti, keutamaan pilihan pengguna, etika penggunaan, keseimbangan antara pengguna dengan penggunaan masa kini dan lampau melalui fungsi penggunaan. Dalam hal ini, kebergantungan masyarakat kini terhadap teori penggunaan yang dibina oleh ahli-ahli ekonomi Barat amat memberi kesan 
terhadap tingkahlaku pengguna.

Dakwaan ini dapat dibuktikan dengan masalahmasalah kegiatan ekonomi seperti masalah pembaziran makanan oleh rakyat Malaysia bernilai RM4.4 trilion setahun (Hishamuddin Rais, 2016); hutang yang tinggi sebagaimana Kajian Indeks Sentimen Pelabur Manulife (MISI) yang mendapati hampir 68 peratus rakyat Malaysia dibebani hutang dan meletakkan Malaysia dalam kelompok lapan pasaran negara di Asia yang mempunyai kadar hutang isi rumah yang tinggi (Aleya Amri, 2016 \& Nur Nazlina Nadzari, 2016); dan isu muflis sebagaimana rekod Jabatan Insolvensi Malaysia, sebanyak 97,215 kes muflis dicatatkan di negara ini sepanjang tempoh 2012 sehingga September 2016. Daripada jumlah itu, sebanyak 22,581 kes, atau 23 peratus, membabitkan kategori dewasa muda, atau Gen Y, yang berumur antara 25 hingga 34 tahun diisytiharkan muflis, selain sebanyak 1,157 kes membabitkan mereka berumur di bawah umur 25 tahun. Menurut Ketua Pegawai Eksekutif Agensi Kaunseling dan Pengurusan Kredit (AKPK), Azaddin Ngah Tasir sebagaimana yang dilaporkan dalam Berita Harian (16 September 2016), antara sebab utama muflis kerana gagal melunaskan pinjaman sewa beli kenderaan membabitkan $26,801 \mathrm{kes}$, atau 27.6 peratus, disusuli pinjaman peribadi $22,153 \mathrm{kes}$, atau 22.8 peratus dan pinjaman perumahan $18,819 \mathrm{kes}$, atau 19.4 peratus.

Hal ini berpunca daripada sikap pengguna itu sendiri khususnya para pengguna Muslim yang tidak jelas mengenai matlamat dan tahap kepenggunaan dari perspektif Islam yang menyebabkan mereka mudah terperangkap dengan fenomena penggunaan dalam sistem ekonomi liberal-kapitalis.

Dalam sistem ekonomi liberal-kapitalis, seseorang pengguna yang membelanjakan pendapatannya bagi tujuan memaksimumkan kepuasan material merupakan sesuatu yang rasional dan sangat digalakkan (Basri Abd. Ghani, Abd Aziz Harjin dan Sayuti Abd. Ghani,
2008; Norliza Abdul Wahid, 2011; Nurshuhaida Abdul Razak \& Siti Zaiton Mohd Dali, 2012). Hal ini kerana kemajuan diukur dengan penggunaan utiliti material yang maksimum. Semakin tinggi kadar kepenggunaan utiliti material, semakin tinggilah tahap kemajuan yang dicapai (Heilbroner, 1962; Bontrup, 1998; Raiklin \& Uyar, 1996:50-52; Gailbraith, 1967). Meskipun begitu, penggunaan maksimum bagi mencapai kepuasan material sebegini boleh menimbulkan kesan negatif seperti pembaziran, keberhutangan yang serius dan muflis. Perkara ini berlaku apabila para pengguna yang berpendapatan rendah terpaksa berhutang untuk memaksimumkan kepuasan penggunaan utiliti material mereka (Norliza Abdul Wahid, 2011).

Dalam keadaan ini, bagaimanakah penggunaan yang sepatutnya diamalkan oleh umat Islam? Apakah ukurannya juga berasaskan kepenggunaan utiliti yang maksimum seperti dalam sistem ekonomi liberal-kapitalis yang banyak diamalkan sekarang ataupun terdapat ukuran yang khusus hingga melahirkan satu bentuk kepenggunaan yang unik? Justeru, kajian ini dilihat sebagai satu inisiatif untuk meneroka satu model kepenggunaan yang lebih berhemah dan terbaik (wasatiyyah). Dalam perkataan lain, ia dikenali sebagai kepenggunaan-wasatiyyah.

Meskipun Kerajaan Malaysia khususnya menjadikan konsep wasatiyyah sebagai penggerak Gagasan 1Malaysia (G1M) dan falsafah pentadbiran Negara, namun setakat ini ia belum dijadikan sebagai pendekatan dalam penggunaan. Aspek kepenggunaan dan konsep wasatiyyah itu dibincang secara terpisah, sedangkan wasatiyyah merupakan satu pendekatan dalam penggunaan. Ketidaksempurnaan aspek penggunaan yang terpisah daripada konsep wasatiyyah menyebabkan timbulnya isu-isu yang dinyatakan sebelum ini. Perkara ini juga menunjukkan pelaksanaan yang bersifat eklektik dan superfisial. Sifat eklektik dan superfisial ini menggambarkan sesuatu yang dijalankan mempunyai masalah ketidaksempurnaan dan tidak menyeluruh. Implikasinya, penyelesaian 
kepada isu-isu kepenggunaan yang berlaku tersebut tidak dapat dilakukan secara holistik dari akar umbi dan bersifat sementara.

Atas alasan tersebut, pembinaan model kepenggunaan-wasatiyyah berdasarkan tujuan maqasid al-syari'ah merupakan sesuatu yang penting bagi menghadapi fenomena kepenggunaan dalam sistem liberal-kapitalis. Secara tidak langsung, ia juga dapat untuk menangani isu-isu kepenggunaan-ghuluw (mengguna mengikut keperluan dan kehendak nafsu masing-masing).

\section{Metodologi}

Kajian kualitatif ini hanya menggunakan data sekunder. Terdapat dua tujuan pengumpulan data sekunder dalam kajian. Pertama, bertujuan meneliti model kepenggunaan konvensional, konsep kepenggunaan Islam dan konsep wasatiyyah. Penelitian dibuat melalui kaedah analisis kandungan terhadap data-data yang dikumpulkan daripada sumber sekunder, iaitu kajian-kajian dan karya-karya terdahulu yang berkaitan seperti tesis, jurnal, dan penulisanpenulisan berkaitan konsep kepenggunaan konvensional, konsep kepenggunaan Islam dan konsep wasatiyyah. Kedua, bertujuan meneroka idea dan struktur model kepenggunaanwasatiyyah yang dilakukan berdasarkan maqasid al-syari'ah. Pembinaan model ini dilakukan dengan merujuk sumber-sumber utama Islam iaitu al-Qur'an dan hadis serta penulisanpenulisan yang berkaitan merangkumi kitabkitab tafsir, kitab-kitab hadis, kitab-kitab sirah dan kajian-kajian berautoriti yang diterbitkan (tesis dan artikel jurnal).

Bagi menganalisis data-data yang dikumpul, kaedah analisis kandungan kualitatif digunakan dalam kajian ini. Bagi tujuan ini, penyelidik akan membaca teks dan mentafsirkannya mengikut tema kajian. Analisis kandungan kualitatif ini adalah menepati keperluan kajian ini kerana penyelidik akan meneliti kajian-kajian dan karya-karya berkaitan konsep kepenggunaan konvensional, konsep kepenggunaan Islam dan

\section{konsep wasatiyyah}

\section{Hasil dan Perbincangan}

\section{Kepenggunaan Konvensional}

Sorotan kajian-kajian lepas mengenai kepenggunaan konvensional telah dibincangkan dengan meluas dan dilihat dari pelbagai sudut iaitu daripada perbincangan umum hinggalah kepada perbincangan yang lebih spesifik. Misalnya, Marshall (1890) yang telah mengembangkan analisis terhadap teori utiliti. Dalam hal ini, Marshall (1890) dikatakan telah menjadi pengasas kepada konsep rasionaliti dan utiliti. Kajiannya telah menjadi asas kepada perkembangan teori ini sekali gus mencetuskan sistem ekonomi kapitalisme baru di Eropah sekitar abad ke-17 hingga ke abad19 (Kahf, 1992a). Seterusnya Weber (1958) seorang sosiologis mengatakan bahawa konsep rasionaliti dalam economic rationalism seperti sistem ekonomi kapitalis tidak sepenuhnya dapat menerangkan fenomena ekonomi di dunia sebenar. Menurut Kahf (1992b), penemuan ini dianggap sebagai satu kajian yang membongkar kelemahan sistem ekonomi kapitalis yang menjadikan konsep rasionaliti sebagai asas kepada perkembangan teori ekonominya sekali gus mengakibatkan tercetusnya pemikiran ekonomi baru iaitu sistem ekonomi sosialis.

Teori penggunaan turut dibincangkan dengan menggunakan pendekatan empirikal dari sudut makroekonomi. Antaranya ialah kajian empirikal oleh A. Pollak (1969) yang telah memperkenalkan jenis fungsi permintaan baru yang telah diterbitkan daripada beberapa masalah dalam teori kepengguaan selain membincangkan teori penggunaan dari aspek mikro dan makroekonomi. Penemuan beliau mendakwa bahawa fungsi utiliti harus disandarkan kepada fungsi pengeluran kumpulan isi rumah dan bukannya individu. Penemuan ini bagaimanapun disangkal oleh Edward dan De Donnea (1977) yang menemui bahawa fungsi utiliti bukan hanya bergantung kepada tahap pengeluaran isi rumah dan individu, tetapi 
turut dipengaruhi oleh teknologi dan citarasa. Kesemua faktor tersebut adalah faktor yang relevan dalam menentukan fungsi utiliti isi rumah (Meadows, 1997). Sementara kajian oleh Anderson (2006) telah mencadangkan satu fungsi penggunaan individu yang cuba memaksimakan utiliti daripada kedua-dua penggunaan semasa dan masa depan. Beliau mendapati terdapat kesan terhadap Master Plan Creation (MPC) iaitu MPC akan lebih kecil daripada MPC asal.

Kajian teori penggunaan dari sudut makroekonomi terus berkembang dengan kajian empirikal oleh Varian (1996). Kajian Varian (1996) ini mendapati bahawa tabungan hanya dilakukan dengan tujuan untuk digunakan pada masa hadapan. Kemudian diikuti oleh kajian oleh Xiootong Jin (2008) yang cuba untuk mengkaji kepekaan penggunaan sebagai salah satu pembolehubah dalam model pembangunan di Negara China. Daripada analisis kajian Xiootong Jin (2008) didapati penduduk China meningkatkan kepekaan pengunaan mereka mengikut keadaan dan tahap ekonomi negara. Kajian oleh Carroll (2009) seterusnya cuba untuk melihat kesan peningkatan pendapatan secara mengejut terhadap penggunaan pengguna dan kesan terhadap garis belanjawan. Kesan tersebut dilihat dengan melihat nisbah peningkatan pendapatan dan perubahan penggunaan.

Berdasarkan sorotan kajian-kajian lepas tentang kepenggunaan konvensional didapati pengkajipengkaji konvensional cenderung memberi penekanan terhadap analisis pilihan pengguna (mikroekonomi) dan penggunaan antara masa (makroekonomi).

\section{Kepenggunaan Islam}

Kebanyakkan ahli ekonomi Islam cenderung untuk membincangkan perkara ini secara berfokus. Misalnya Khaf (1992a) yang membincangkan matlamat seorang pengguna Muslim dalam kegiatan penggunaannya. Menurut Khaf (1992a), pengguna Muslim patut mengutamakan akhirat berbanding dunia.
Pada asasnya seorang Muslim akan dihadapkan dengan dua pilihan iaitu antara menggunakan barang ekonomi yang bersifat duniawi sahaja dengan barang ekonomi yang bersifat ibadah (ukhrawi). Menurut Khaf (1992a) lagi, pengunaan barang untuk keperluan ibadah lebih bernilai berbanding dengan penggunaan untuk duniawi. Hal ini kerana orientasi penggunaannya adalah al-falah iaitu untuk mendapatkan pahala daripada Allah SWT sehingga lebih bertujuan untuk kehidupan akhirat kelak. Semakin besar penggunaan untuk ibadah maka semakin tinggi pula al-falah yang akan dicapai.

Turut menyokong al-falah sebagai matlamat pengguna Islam ialah Siddiqi (1992). Menurut Siddiqi (1992), tujuan mencapai al-falah di dunia dan di akhirat merupakan matlamat utama pengguna dalam merasionalkan kehendak dan keperluan supaya selari dengan utiliti dalam penggunaan mereka.

Sementara perbincangan mengenai konsep rasionaliti dan utiliti juga mendapat perhatian cendiakawan Islam. Antaranya kajian oleh Syed Omar Syed Agil (1990) yang membincangkan secara kritis konsep rasionaliti dari perspektif Islam dan konvensional. Menurut Syed Omar Syed Agil (1990), rasional pengguna tidak seharusnya dipisahkan daripada agama. Pegangan agama sangat berkait rapat dalam menentukan kelakuan seseorang. Kemudian kajian oleh Biraima (1991) pula mengariskan teori ekonomi Qur'anic yang telah mengintegrasikan ekonomi ortodoks (pemaksimuman utiliti sebagai prinsip yang akan menentukan rasional pilihan) dengan ekonomi Islam (pemaksimuman iman sebagai prinsip yang akan menentukan pilihan untuk pengguna Muslim yang rasional). Gabungan prinsip ini berperanan sebagai MPC. Hasil kajian ini mendapati terdapat hubungan songsang antara pemaksimuman kehendak dengan kesedaran mengenai alam baqa' (akhirat).

Hal ini berbeza dengan Mannan (1993) yang mengatakan rasionaliti dalam ekonomi Islam sentiasa mengambil kira aspek kemaslahatan. 
Pengguna haruslah meletakkan keutamaan dengan kekangan pendapatanya yang ada padanya. Pendekatan ini juga menurut beliau harus diaplikasikan kepada semua jenis keperluan maqasid al-syari 'ah iaitu untuk menjaga agama, nyawa, akal, zuriat dan harta.

Turut juga membincangkan aspek rasionaliti dalam kepenggunaan Islam ini ialah kajian yang Abdul Aziz Sahidin, Azizah M. Isa, Mohd Shukor Abdul Manan dan Habibah Lehar (2000), Basri Abd. Ghani, Abd Aziz Harjin dan Sayuti Abd. Ghani (2008), Norliza Abdul Wahid (2011), dan Nurshuhaida Abdul Razak dan Siti Zaiton Mohd Dali (2012). Berdasarkan kajian-kajian ini, didapati dalam ekonomi Islam pengguna dianggap rasional apabila mereka membelanjakan pendapatan yang diperoleh bagi tujuan memaksimumkan kepuasan material sejajar dengan kepuasan kerohanian. Utiliti material akan menjadikan mereka sangat puas di dunia ini, manakala utiliti kerohanian membuatkan mereka puas di akhirat kelak. Maka dengan itu, pendapatan digunakan bukan sahaja untuk memenuhi utiliti material, bahkan juga memenuhi utiliti kerohanian. Contohnya, di samping seseorang itu membelanjakan pendapatan untuk makanan, pakaian, dan keperluan-keperluan lain, mereka mungkin juga mahu membelanjakan sebahagian pendapatan yang diperoleh sebagai derma kepada yang memerlukan. Mereka membuat keputusan perbelanjaan bukan sahaja berdasarkan pemikiran sendiri, tetapi juga yang lebih penting berasaskan nilai-nilai agama iaitu agama Islam.

Walau bagaimanapun, konsep kepenggunaan dalam ekonomi Islam yang dibincangkan oleh Abdul Aziz Sahidin, Azizah M. Isa, Mohd Shukor Abdul Manan dan Habibah Lehar (2000), Basri Abd. Ghani, Abd Aziz Harjin dan Sayuti Abd. Ghani (2008), Norliza Abdul Wahid (2011), dan Nurshuhaida Abdul Razak dan Siti Zaiton Mohd Dali (2012) masih terikat dengan konsep kepenggunaan dalam ekonomi konvensional iaitu memaksimumkan kepuasan material. Cuma yang bezanya, mereka cuba memasukkan elemen utiliti kerohanian. Hal inilah yang dikatakan sebagai mengakomodatif dan memodifikasikan konsep kepenggunaan dalam ekonomi konvensional yang dirasakan tidak bertentangan dengan syariat Islam, lalu diguna pakai dalam ekonomi Islam.

Perkara yang sama juga telah dilakukan oleh Fadhilah Mat Nor, Aza Shahnaz Azman, Mawar Murni Yusnos dan Abdul Ghafar Ismail (2016) yang menyatakan pengguna dianggap rasional apabila mereka membelanjakan pendapatan mereka untuk memaksimumkan kepuasan material sejajar dengan kepuasan kerohanian. Utiliti material akan menjadikan mereka sangat puas di dunia ini, manakala utiliti kerohanian membuatkan mereka puas di akhirat. Bagi menyokong pernyataan ini, mereka menyatakan al-Qur'an sendiri menegaskan kepuasan yang hakiki hanyalah kebaikan yang diperoleh di dunia dan di akhirat. Jelas di sini bahawa, kajian yang dilakukan oleh Fadhilah Mat Nor, Aza Shahnaz Azman, Mawar Murni Yusnos dan Abdul Ghafar Ismail (2016) masih lagi meletakkan memaksimumkan kepuasan material di dunia sejajar dengan kepuasan kerohanian di akhirat. Sedangkan ayat 77 daripada Surah al-Qasas mengutamakan kepuasan kerohanian (akhirat) berbanding memaksimumkan kepuasan material (dunia).

Melihat aspek lain, aspek pilihan penggunaan juga dibincangkan oleh para ilmuan Islam. Misalnya Afzal-ur-Rahman (1975) yang membahagikan keutamaan penggunaan kepada empat komponen iaitu barang keperluan asas, barang keperluan kecekapan, barang keselesaan, dan barang kemewahan. Sementara Mannan (1980) dan Muslehuddin (1980) telah membahagikan keutamaan penggunaan kepada tiga jenis iaitu penggunaan barang keperluan asas, barang keselesaan, dan barang kemewahan. Walaubagaimanapun menurut Sadeq (1987) pula terdapat enam jenis keutamaan penggunaan iaitu barang keperluan hidup, barang keperluan asas, barang keselesaan, barang kemewahan, barang merbahaya dan barang keperluan kecekapan.

Perkembangan kepenggunaan dari perspektif 
Islam juga tidak ketinggalan daripada membincangkan kelakuan pengguna. Misalnya, Khan (1983) yang telah memperincikan perbincangan tentang kelakuan pengguna menurut perspektif Islam. Menurut beliau seorang Muslim seharusnya beretika dan mengikut norma-norma Islam semasa menggunakan barang dan perkhidmatan. Dalam hal ini, para pengguna Muslim harus mengutamakan maslahah berbanding kepuasan utiliti untuk memenuhi kehendak yang terbatas. Berhubung perkara ini, Kahf(1992b) menambah terdapat tiga prinsip dasar yang menjadi asas kepada teori kelakuan pengguna iaitu keyakinan kewujudan hari akhirat, konsep al-falah serta fungsi dan kedudukan harta.

Selain perbincangan tentang pilihan dan keutamaan pengguna, cendiakawan Islam juga cenderung mengenengahkan perbincangan mengenai fungsi penggunaan seperti ahli ekonomi barat dalam perbincangan teori penggunaan konvensional. Misalnya, kajian oleh Munawar (1985) yang cuba mengulas tentang perubahan ke atas fungsi penggunaan sebagai kesan daripada pengaplikasian ekonomi zakat berbanding pengaplikasian cukai dalam ekonomi konvensional. Kajian Munawar (1985) ini telah menyokong pendapat Khaf (1984) yang mengatakan bahawa tabungan yang tidak disertai dengan keputusan untuk melabur hanya akan menjadikan keluk puas sama pengguna menjadi lebih rendah. Kajian Munawar (1985) ini telah diperkukuhkan lagi oleh kajian Khan (1990) yang mengulas isu yang sama iaitu pengaplikasian zakat ke atas fungsi penggunaan dengan contoh metematik dan gambarajah aliran.

Selain itu terdapat juga perbincangan berkaitan adab dan peraturan kepenggunaan dalam ekonomi Islam. Misalnya, kajian Noor Ashikin Hamid, Nur Amani Pauzai dan Shariffah Nuridah Aisyah Syed Nong (2011) yang pengguna diberi kebebasan sepenuhnya dalam menggunakan sesuatu barangan atau perkhidmatan untuk mendapat kesejahteraan hidup, namun penggunaan itu tertakluk kepada adab dan peraturan yang ditetapkan oleh Allah SWT.

Berbeza dengan kajian-kajian sebelum ini, Mohammad Aizat Jamaludin, et. al. (2012) mengkaji tentang kepenggunaan Islam dari aspek halal. Kepenggunaan halal ini lebih bersifat hukum atau menekankan soal halal haram. Selain itu, ia juga melibatkan konsep halalan tayyiban, proses penghasilan produk halal, pengenalpastian logo halal, etika kepenggunaan, hak-hak pengguna Muslim dan perundangan yang berkaitan kepenggunaan halal. Kajian Mohammad Aizat Jamaludin, et.al. (2012) ini berbeza dengan kajian-kajian dan karya-karya yang dihasilkan oleh Abdul Aziz Sahidin, Azizah M. Isa, Mohd Shukor Abdul Manan dan Habibah Lehar (2000), Basri Abd. Ghani, Abd Aziz Harjin dan Sayuti Abd. Ghani (2008), Norliza Abdul Wahid (2011), Nurshuhaida Abdul Razak dan Siti Zaiton Mohd Dali (2012) dan Noor Ashikin Hamid, Nur Amani Pauzai dan Shariffah Nuridah Aisyah Syed Nong (2011) sebelum ini, kerana ia lebih menumpukan kepada aspek halal.

Soroton kajian-kajian lepas tentang kepenggunaan Islam banyak menyentuh perbincangan seperti matlamat penggunaan, konsep rasionaliti, pilihan pengguna, etika kepenggunaan, dan penggunaan masa kini dan masa lampau. Hal ini menunjukkan masih terdapat lompang yang perlu diisi dan dikaji iaitu aspek kepenggunaan-wasatiyyah yang menumpukan kepada aspek tahap penggunaan. Dalam perkataan lain, model kepenggunaanwasatiyyah yang akan dibina ini tidak menyerap masuk elemen-elemen kepenggunaan konvensional yang jelas tidak beracuankan maqasid al-syari'ah.

\section{Konsep Wasatiyyah}

Menurut Chandra Muzaffar (2011), wasatiyyah merupakan satu konsep kompleks dan universal yang tidak mudah diterjemahkan ke dalam bahasa lain. Ia merupakan satu falsafah Islam yang memerlukan penghayatan yang mendalam. 
Dalam al-Qur'an, wasatiyyah diungkapkan dengan istilah wasatan. Ungkapan ummatan wasatan dalam ayat 143 Surah al-Baqarah (2) dikhususkan kepada umat Islam. Ummatan wasatan bermaksud umat yang pertengahan, iaitu cemerlang dalam setiap aspek (Ismail Ibrahim, 2012; Zulkifli Mohamad al-Bakri, 2011 \& Mohd Shukri Hanapi, 2014), adil (Chandra Muzaffar, 2011; Ali Muhammad alSalabiy, 1999:41; Mohd Najib Abdul Razak, 2015a \& 2015b; Abdullah Md Zin, 2013:12), mulia, maju (Zulkifli Mohamad al-Bakri, 2011), terbaik (Mahmud Abdul Rahman, 2015:147) dan seimbang (Chandra Muzaffar, 2011).

Selain maksud cemerlang, keadilan, kemuliaan dan kemajuan, terbaik dan seimbang, terdapat beberapa penulis yang mengemukakan maksud ummatan wasatan dengan maksud moderation. Misalnya, Ismail Ibrahim (2012:39) yang menyatakan istilah wasat merupakan istilah yang menyamai moderation dan equilibrium. Namun begitu, istilah wasat tiada kena mengena dengan istilah moderation. Ia merupakan dua istilah yang berbeza. Istilah moderation ini telah diperkenalkan oleh golongan Barat yang bermaksud melonggarkan ajaran agama. Hal ini berbeza dengan istilah wasatiyyah yang diamalkan bersandarkan epistemologi Islam. Sebenarnya, kaum Muslimin hanya menggunakan istilah moderation ini supaya golongan Barat memahami konsep wasatiyyah yang dibincangkan oleh umat Islam.

Menurut Zulkifli Mohamad al-Bakri (2011:15), ummatan wasatan merupakan gelaran yang diberikan oleh Allah SWT kepada umat Islam. Hal ini membuktikan bahawa umat Islam mempunyai ciri-ciri keistimewaan yang unggul serta dapat membezakan antara umat Islam dengan umat lain dan menjadikan umat Islam sebagai umat terbaik (Ali 'Imran, 3:110).

Penjelasan tentang maksud ummatan wasatan yang dikemukakan oleh Zulkifli Mohamad alBakri (2011) adalah berbeza dengan pandangan Ismail Ibrahim (2012). Menurut Ismail Ibrahim (2012), ummatan wasatan ialah umat yang dinamik, kuat, dan maju dalam bentuk dan agenda perjuangan yang sejajar dengan agama dan ajarannya yang lengkap serta menyeluruh, bukan merupakan umat yang mengambil sesetengah bahagian sahaja daripada ajaran agamanya.

Seterusnya, ummatan wasatan yang dimaksudkan oleh Mahmud Abdul Rahman (2015:147) juga berbeza dengan maksud yang dikemukakan oleh Zulkifli Mohamad al-Bakri (2011) dan Ismail Ibrahim (2012). Menurut Mahmud Abdul Rahman (2015), ummatan wasatan merujuk kepada umat Islam yang konsisten menjadi umat terbaik selagi umat Islam memelihara sifat kesederhanaan ini yang menggambarkan keseimbangan dan istiqamah di jalan Allah SWT. Oleh yang demikian, Wan Kamal Mujani, Ermy Azziaty Rozali dan Nor Jamaniah Zakaria. (2015) menegaskan pada hari ini konsep wasatiyyah telah dijadikan sebagai penggerak Gagasan 1 Malaysia (G1M) oleh Perdana Menteri Malaysia iaitu Dato' Seri Mohd Najib bin Tun Abdul Razak. Berdasarkan konsep ini, semua rakyat diseru agar mengimbangi antara tuntutan rohani dengan jasmani; antara hambatan dunia dengan akhirat, kerana keseimbangan dan kesederhanaan ini amat penting dalam mewujudkan perpaduan dan keharmonian hidup, seterusnya menentukan kejayaan individu, keluarga, masyarakat dan negara.

Di samping itu, konsep wasatiyyah ini telah mengemukakan beberapa asas bagi menjaga keharmonian dan mewujudkan persefahaman dalam masyarakat yang berbeza agama dan budaya. Hal ini kerana, wasatiyyah merupakan pendekatan yang bersifat menyeluruh dan bersepadu yang mampu menyelesaikan tuntutan serta permasalahan ummah (Abdullah Md Zin, 2013:13; Wan Kamal Mujani, Ermy Azziaty Rozali \& Nor Jamaniah Zakaria, 2015).

Sebenarnya konsep wasatiyyah merupakan satu pendekatan yang sangat wajar diguna pakai dalam setiap aspek kehidupan dan dijadikan asas kepada pembentukan peribadi Mukmin 
yang seterusnya akan menyumbang kepada pembangunan Islam. Konsep ini selaras dengan tuntutan masyarakat Islam bagi mempersiapkan diri supaya menjadi umat yang cemerlang dan terbaik, di samping menjaga hubungan dengan Allah SWT dan menjaga hubungan sesama manusia (Syaidatana Siti Aishah Ab Aziz, 2014:9).

Menurut Mohd Ridhuan Tee Abdullah (2012), konsep wasatiyyah ini dituntut agar diamalkan dalam Islam supaya umat Islam menjadi umat yang terbaik. Setiap manusia boleh menjadi kaya-raya, tetapi jangan sampai melupakan tanggungjawab kepada Allah SWT. Seterusnya, boleh membangun, tetapi jangan sampai pembangunan itu merosakkan diri manusia dan alam sekeliling.

Selain itu, Mohd Shukri Hanapi (2014:51) menyatakan konsep wasatiyyah merupakan salah satu daripada ciri-ciri khusus tasawur Islam. Ia bertujuan mengimbangi tindakan yang ekstrem dalam setiap aspek kehidupan manusia. Oleh itu, umat Islam diseru untuk mengamalkan amalan kesederhanaan ini. Hal ini adalah untuk mempertingkatkan kualiti hidup manusia dalam pelbagai aspek kehidupan, bermula daripada kefahaman keagamaan, hinggalah kepada hubungan individu dengan masyarakat, serta aspek-aspek pengurusan dan pembangunan Islam.

Sebagaimana yang dijelaskan sebelum ini, konsep wasatiyyah merupakan satu pendekatan yang mengamalkan ajaran Islam secara berimbang dan komprehensif dalam segenap bidang kehidupan. Misalnya, membantu mempertingkatkan kualiti hidup ummah, sama ada dari segi pembangunan ilmu pengetahuan, pembangunan insan, sistem ekonomi serta kewangan, pertahanan dan sebagainya (Abdullah Md Zin, 2012:48).

Konsep wasatiyyah ini sesuai diaplikasikan dalam kehidupan seharian kerana masyarakat Islam telah lama mengamalkan konsep ini dalam setiap aspek kehidupan (Mohd Yusof Othman,
2013). Contohnya, konsep wasatiyyah ini telah diamalkan oleh masyarakat Malaysia sejak tahun 1957 iaitu selepas mencapai kemerdekaan. Ia diamalkan terutamanya dalam isu-isu berkaitan dengan agama (Abdullah Md Zin, 2014:17).

Menurut Abdul Monir Yaacob (2015:112), wasatiyyah merupakan satu konsep yang wujud dalam Islam. Ia mempunyai nilai sejagat yang boleh diaplikasikan dalam pelbagai bidang termasuklah dalam aspek kepenggunaan. Hal ini kerana, konsep wasatiyyah lebih menjurus kepada pembentukan umat Islam yang mempunyai sikap dan tindakan serta amalan yang tidak ekstrem atau condong kepada sikap radikal dan melampaui batas dalam setiap aspek kehidupannya (Ismail Ibrahim, 2012:32).

Konsep wasatiyyah dipilih untuk dijadikan sebagai pendekatan dalam kepenggunaan kerana ia merupakan salah satu pendekatan yang berpotensi dan mampu menyelesaikan permasalahan ummah (Abdullah Md Zin, 2013). Menurut Khader Ahmad, Mohd Farhan Md Ariffin, Mohd Khairi Shafie, Sedek Ariffin, Fauzi Deraman dan Mustafa Abdullah (2016), konsep wasatiyyah ini mampu menarik minat manusia kepada agama, sekali gus membuktikan bahawa Islam merupakan agama yang mendisiplinkan umatnya dengan hukum dan peraturan.

\section{Konsep Maqasid al-Syariah}

Secara asasnya, maqasid al-syari 'ah merupakan tujuan di sebalik pensyariatan sesuatu hukum. Ia merupakan satu disiplin ilmu yang dijadikan sebagai pengukur kepada pelaksanaan sesuatu perkara sama ada ia selari dengan syariat Islam atau tidak.

Maqasid al-syariah bersifat murakkab atau terdiri daripada dua patah perkataan iaitu maqasid dan al-syariah (Zulkifli Mohammad al-Bakri, 2014:1). Maqasid bermaksud tujuan. Dalam bahasa Arab, akar kata kepada perkataan maqasid ialah qasd. Perkataan ini membawa pelbagai makna antaranya menuju, arah, berjalan lurus, memecahkan, pegangan, punca, kelurusan, 
keadilan, dan kesederhanaan (Ibn Manzur, 1993 \& al-Fayruz Abadi, 1997:449 ). Begitu juga dengan Ismail al-Hasani (1995:114-115) yang menyatakan istilah maqsad bermaksud menuju, tetapi penggunaannya lebih kepada aspek bahasa. Ia juga memberi maksud kesederhanaan dan pertengahan antara dua perkara (Zaharuddin Abd Rahman, 2014:5).

Firman Allah SWT yang bermaksud:

"Dan bersederhanalah ketika kamu berjalan dan rendahkanlah suaramu. Sesungguhnya seburuk-buruk suara ialah suara keldai." (Qur'an, 31:19)

Firman-Nya lagi yang bermaksud:

"Kemudian kitab ini Kami wariskan kepada orang yang Kami pilih di antara hambahamba Kami, lalu di antara mereka ada yang pertengahan dan ada (pula) yang lebih dahulu berbuat kebaikan dengan izin Allah. Yang demikian itu adalah kurniaan yang besar." (Qur'an, 35:32)

Perkataan syariah pula berasal daripada perkataan Arab syara'. Dari segi bahasa adalah jalan yang lurus. Zulkifli Mohamad alBakri (2014) mendefinisikan syariah sebagai perundangan-perundangan yang diturunkan Allah SWT kepada Rasulullah SAW kepada manusia. Misalnya ibadah, akhlak, makanan, minuman, pakaian dan muamalah. Ibn Manzur (1993) pula menyatakan syariah bermaksud menerangkan serta menunjukkan jalan.

Apabila digabungkan perkataan maqasid alsyariah maka terbentuklah istilah maqasid alsyariah. Al-Raysuni (1996:19) mendefinisikan maqasid al-syariah adalah matlamat yang ditentukan oleh syarak untuk dilaksanakan bagi memberi kebaikan kepada para hamba-Nya. Al'Alim (1997) pula menyatakan bahawa maqasid al-syariah adalah kebaikan yang diperoleh oleh para hamba sama ada dengan cara melakukan perkara kebaikan atau meninggalkan perkara kejahatan. Senada dengan al-‘Alim (1997) ialah
al-Qaradawi (2000) yang menyatakan maqasid al-syariah adalah sebagai tujuan pensyariatan hukum untuk membolehkan manusia mengecapi kebaikan dan menolak keburukan. Definisi yang digunakan dalam kertas kerja ini ialah definisi yang dinyatakan oleh al-Raysuni (1996:19) kerana maksudnya jelas iaitu matlamat yang ditentukan oleh syarak kepada manusia untuk dilaksanakan bagi mencapai mardat Allah.

Al-Syatibi (t.th:17) dan al-Ghazali (1996:139), membahagikan maqasid syariah kepada tiga komponen iaitu keperluan asas (daruriyyah), keperluan biasa (hajiyyah), dan keperluan keselesaan (tahsiniyyah), Menurut Ghilman Nursidin (2012), komponen-komponen ini dikategorikan mengikut tahap kepentingannya. Sebenarnya, pembahagian ini terlebih dahulu dipelopori oleh Imam al-Haramayn al-Juwayniy. Kemudian ia menjadi ikutan para ulama selepas beliau seperti al-Ghazaliy, al-'Izz 'Abd alSalam, al-Qarafiy, Ibn al-Taimiyyah, Ibn alQayyim dan al-Syatibiy.

Walau bagaimanapun, secara lebih khusus lagi Sadeq (1983) membahagikannya kepada lima komponen iaitu barang keperluan asas (daruriyyah), barang keperluan biasa (hajiyyah), barang keperluan keselesaan (tahsiniyyah), barang keperluan kemewahan, dan barang merbahaya atau merosakkan. Bagi tujuan pembinaan model kepengunaan-wasatiyyah dalam kajian ini, kelima-lima komponen ini akan digunapakai.

\section{Model Kepenggunaan-Wasatiyyah}

Perbincangan model kepenggunaan-wasatiyyah dalam makalah ini terbahagi kepada tiga bahagian. Pertama, falsafah kepenggunaanwasatiyyah; kedua, tahap kepenggunaanwasatiyyah; dan ketiga, matlamat kepenggunaanwasatiyyah. 


\section{Falsafah Kepenggunaan-Wasatiyyah}

Falsafah merupakan dasar dan garis panduan bagi sebuah sistem ekonomi yang dibina. (Khurshid Ahmad, 1980; Kahf, 1989:72). Dalam kajian ini, tauhid dijadikan sebagai falsafah kepenggunaan-wasatiyyah. Hal ini dapat membezakan antara kepenggunaan-wasatiyyah dengan kepenggunaan konvensional.

Tauhid bermaksud penyerahan diri, mengakui dan mempercayai sepenuhnya keesaan Allah SWT (al-Qaradawi, 1995:31; al-Ikhlas, 112:13). Kepercayaan dan keyakinan ini merangkumi pengakuan bahawa Allah SWT adalah Pencipta, Pemilik dan Penguasa mutlak alam ini (Tauhid Rububiyyah) dan mengaku bahawa Allah SWT sahaja yang wajib disembah dan ditaati (Tauhid Uluhiyyah) (Sardar, 1990; al-Qaradawi, 1995; Khalijah, 2011). Landasan tauhid yang kukuh akan dapat mengimplementasikan syariah dan akhlak dengan baik. Maknanya semua aktiviti yang dilakukan adalah dalam kerangka mencorakan kehidupan yang sesuai dengan kehendak Allah SWT. Dalam konteks kepenggunaan, ia akan mencorakkan satu sistem kepenggunaan yang semata-mata mementingkan kepuasan meterial sahaja, dan mengabaikan aspek kepuasan kerohanian.

Jelas di sini bahawa, tauhid merupakan perkara paling asas dalam cara hidup Islam serta mempunyai kedudukan terpenting dalam kehidupan manusia (Surtahman Kastin Hasan, 2011). Ia merupakan tonggak atau tunjang kepada segala aspek kehidupan manusia umumnya dan aktiviti kepenggunaan khususnya (Abdul Halim Abd Kadir, Nor Azzah Kamri \& Baharom Kassim, 2013). Pendekatan tauhid ini bukan sekadar membantu memenuhi keperluan individu semata-mata dalam menyediakan segala bentuk perancangan dalam kehidupan mereka secara komprehensif, tetapi, turut memfokuskan tanggungjawab penciptaan manusia di alam ini iaitu beribadat kepada Allah SWT.

\section{Tahap Kepenggunaan-Wasatiyyah}

Kepenggunaan-wasatiyyah dapat direalisasikan apabila para pengguna membelanjakan pendapatannya mengikut keperluan dan bukannya memaksimumkan kepuasan material seperti dalam sistem liberal-kapitalis. Sebelum direalisasikan kepenggunaan-wasatiyyah ini, tahap-tahapnya perlu dibina terlebih dahulu. Dalam kajian ini, pembinaan tahap-tahap kepenggunaan-wasatiyyah dibuat berdasarkan komponen-komponen dalam maqasid alsyari 'ah iaitu daruriyyah (keperluan asas/ hidup), hajiyyah (keperluan tambahan), tahsiniyyah (keperluan pelengkap/keselesaan), kamaliyyah (keperluan kemewahan), dan barang merbahaya atau merosakkan.

\section{Penggunaan Untuk keperluan Daruriyyah}

Ia merujuk kepada penggunaan untuk memenuhi segala keperluan kehidupan atau keperluan asas manusia dengan memelihara lima perkara (daruriyyat al-khams) iaitu agama, nyawa, akal, harta dan keturunan. Dalam hal ini, kepenggunaan yang diharuskan untuk keperluan hidup adalah seperti menggunakan sejumlah wang untuk membeli makanan dan minuman bagi menjaga maslahah nyawa (alBaqarah, 2:35); membeli pakaian bagi menjaga maslahah agama dan kehormatan (al-A'raf, 7:26); menyediakan tempat tinggal atau rumah bagi menjaga maslahah nyawa (al-Syu'ara': 128-129); membayar kos pendidikan bagi memenuhi maslahah akal; dan keperluan untuk mendapatkan perubatan bagi tujuan maslahah nyawa. Kepenggunaan yang dilakukan untuk memenuhi keperluan asas hidup ini adalah sangat penting kerana maqasid daruriyyah. Ia merupakan maslahah yang menentukan keseimbangan antara kehidupan agama dengan keduniaan manusia. Sekiranya perkara ini tidak dipenuhi nescaya akan berlaku kepincangan hidup manusia di dunia dan kehilangan nikmat yang abadi. 


\section{Penggunaan Untuk Keperluan Hajiyyah}

Ia merujuk kepada penggunaan wang untuk mendapatkan sesuatu yang tidak berhubung dengan keperluan asas manusia, tetapi ia merupakan keperluan tambahan yang diperlukan oleh manusia untuk memudahkan kehidupan mereka dan memberikan keselesaan hidup. Apabila keperluan hajiyyah ini tidak dipelihara, maka ia tidaklah menjejaskan kehidupan manusia, tetapi boleh membawa kepada kesusahan dan kesempitan hidup. Perbelanjaan dalam keperluan hajiyyah ini kebiasaannya hanya dilaksanakan apabila keperluan daruriyyah sudah dipenuhi. Penggunaan untuk keperluan hajiyyah yang dibenarkan adalah seperti berhutang untuk membeli kenderaan bagi memudahkan urusan kehidupan dan memenuhi hajat dengan mengikut kemampuan. Selain itu, hutang yang dibuat atas tujuan mendapatkan keselesaan tempat tinggal, berpakaian, makan dan minum juga adalah dibenarkan kerana ia boleh menyebabkan seseorang gembira serta meningkatkan kecekapan kerja. Selain itu, syarak juga telah memberikan kebebasan kepada manusia untuk menikmatinya. Meskipun begitu, umat Islam tidak dianjurkan untuk berlebihlebihan sehingga berlakunya pembaziran kerana ia akan menyebabkan hilangnya keluhuran budi pekerti (Qur'an, 25:67).

\section{Penggunaan Untuk Keperluan Tahsiniyyah}

Keperluan tahsiniyyah ini merupakan pelengkap yang menjadi hiasan tambahan dalam kehidupan. Dengan keberadaannya, maka kehidupan manusia akan menjadi lebih sempurna. Ketiadaannya tidak akan menyusahkan hidup manusia dan tidak akan mendatangkan kesempitan, tetapi kehidupan manusia akan terkeluar daripada adab-adab yang terpuji yang dituntut oleh maruah dan adabadab umum dalam masyarakat bertamadun. Jika tidak dipelihara kemaslahatan tersebut, maka ia akan menyebabkan kehidupan menjadi buruk pada pandangan akal. Al-Qur'an juga ada menyuruh umat Islam supaya menikmati perkara yang baik dan indah. Sebagai contoh, dalam berhutang seseorang individu dibenarkan untuk berhutang dengan tujuan mengadakan majlis peminangan dan pernikahan bagi menyempurnakan upacara akad nikah. Begitu juga berhutang untuk memiliki sebuah lagi kereta sekiranya mempunyai keperluan dan kemampuan. Dibenarkan juga berhutang untuk memiliki rumah yang sesuai, untuk membeli hiasan dan perkakas rumah yang cantik, bungabungaan kerana semua ini melambangkan ciri ketenangan dan kebahagiaan yang diharuskan dalam Islam (Qur'an, 7:32).

Menikmati keselesaan dibenarkan dalam Islam. Agama Islam sendiri mengiktiraf keinginan semulajadi manusia yang inginkan kecantikan dan keindahan serta perkara-perkara yang baik. Namun, keinginan ini tidak melampaui batas atau membazir. Pembahagian ini sengaja dijelaskan oleh para ulama untuk membantu umat Islam dalam menentukan priority atau keutamaan dalam melakukan ketaatan dalam hidup mereka.

\section{Penggunaan Untuk Keperluan Kemewahan}

Ia merujuk kepada penggunaan dalam mendapatkan barang yang tidak diperlukan untuk keselesaan, tetapi kebiasaannya untuk prestige atau bermegah-megah serta melampaui batas. Perbelanjaan untuk memperoleh keperluan kemewahan biasanya lebih besar daripada faedah yang dapat dinikmati. Misalnya, seseorang itu berhutang semata-mata untuk membeli kereta yang berharga jutaan ringgit. Biasanya barang ini hanya digunakan oleh golongan yang berada. Bagi tujuan mendapatkan barang sebegini dalam kalangan pengguna yang berpendapatan sederhana atau rendah, mereka pasti perlu membuat pembiayaan atau hutang yang tinggi. Oleh sebab barang mewah sering menjadi lambang kedudukan seseorang lebihlebih lagi masyarakat sekarang yang bersifat materialistik, maka ia sangat ditagih. Barangan mewah ini umumnya tidak digalakkan kerana ia akan menimbulkan sikap berlagak dan mengikut hawa nafsu yang akan merugikan umat Islam. 
Oleh itu, hutang untuk mendapatkan barangan kemewahan adalah ditegah oleh Islam kerana penggunaan barangan mewah merupakan racun yang membunuh secara perlahan-perlahan. Ia pasti akan membinasakan diri sendiri, keluarga dan masyarakat seperti berlakunya amalan rasuah, sikap malas bekerja dan kes muflis yang melanda kehidupan golongan generasi $\mathrm{Y}$ pada masa kini.

Hal ini selari dengan pandangan Jon Hanson (2005) yang mengibaratkan hutang sebagai kolesterol. Seperti kolesterol, hutang jika dilakukan untuk mengejar kemewahan hidup, ia akan mendatangkan masalah kepada individu, malah ada kalannya boleh membunuh. Sebenarnya perkara yang dinyatakan oleh Jon Hanson (2005) ini ada kebenarannya. Kes-kes jenayah yang berkaitan dengan along seperti ugutan, bunuh diri, dan sebagainya merupakan antara kesan buruk yang timbul akibat tabiat suka berhutang untuk kemewahan semata-mata.

Penggunaan Untuk Barang Merbahaya Yang Boleh Merosakkan

Ia merujuk kepada penggunaan untuk mendapatkan barang yang boleh membawa mudarat sama ada kepada penggunanya atau masyarakatnya. Penggunaan seperti ini adalah adalah dilarang. Contonhya, berhutang untuk membuka perusahaan sesuatu yang memabukkan dan menghancurkan budi pekerti seperti, dadah, arak dan pusat perjudian. Perkara ini dilarang dalam agama Islam kerana ia boleh memudaratkan penggunanya dan masyarakat. Hal ini kerana ia akan menghilangkan kewarasan dan melakukan tindakan yang tidak sepatutnya serta menyebabkan gejala sosial semakin berleluasa.

Selain itu, diharamkan berhutang untuk membuka pusat pelacuran. Hal ini kerana Islam mengharamkan segala jenis hubungan yang dilakukan atas dasar pelacuran melainkan pernikahan yang sah. Hal ini menunjukkan Islam begitu menjaga kehormatan umat Islam daripada perkara yang membawa kepada kehancuran (Qur'an, 17:32). Dalam hal ini, hutang untuk barang merbahaya atau merosakkan adalah diharamkan dalam Islam kerana ia memberikan kesan dan bahaya kepada individu dan masyakarat

\section{Matlamat Kepenggunaan-Wasatiyyah}

Terdapat dua matlamat kepenggunaanwasatiyyah, iaitu bertujuan (a) mencapai kebaikan; dan (b) mencapai keredaan Allah SWT.

\section{Mencapai Kebaikan}

Matlamat bagi aktiviti kepenggunaan adalah untuk mencapai kesejahteraan hidup. Namun, kesejahteraan dalam konteks ekonomi konvensional diukur berdasarkan tahap seseorang individu dapat memuaskan pelbagai kehendak terhadap barangan dan perkhidmatan semata-mata (Basri Abd. Ghani, Abd Aziz Harjin \& Sayuti Abd. Ghani, 2008). Allah SWT memberi peringatan yang jelas kepada mereka yang hanya menumpukan aspek kebendaan semata-mata (Qur'an, 10:7-8 \& 11:15-16), iaitu mereka yang hanya mementingkan kepuasan material tanpa mengambil kira soal kepuasan kerohanian.

Jelas di sini bahawa kesejahteraan atau kepuasan yang hakiki hanya kebaikan yang diperoleh di dunia dan di akhirat. Pengguna dianggap rasional apabila mereka membelanjakan pendapatan mereka untuk kepuasan material mengikut keperluan (bukan unlimited want) sejajar dengan kepuasan kerohanian. Utiliti material akan menjadikan pengguna mencapai kebaikan di dunia ini, manakala utiliti kerohanian membuatkan mereka mencapai kesejahteraan di akhirat kelak.

\section{Mencapai Keredaan Allah SWT}

Apabila setiap amalan kebaikan dilakukan dengan penuh ketauhidan, keikhlasan dan mematuhi syariat yang dibawa oleh Rasulullah SAW, maka ia akan diredai Allah SWT. Setelah 
mendapat keredaan Allah SWT, seseorang hamba itu akan mendapat al-falah di dunia dan di akhirat sebagai hasilnya.

Di sini dapat dirumuskan bahawa keredaan Allah SWT itu merupakan matlamat akhir kepada segala bidang yang manusia usahakan, termasuklah aktiviti kepenggunaan. Kesan daripada mendapat keredaan Allah SWT ini, manusia akan mendapat al-falah di penghujungnya. Namun begitu, untuk mendapatkan keredaan Allah SWT ini manusia perlu memenuhi tiga syarat utama. Pertama, kepenggunaan yang dilaksanakan mestilah ikhlas semata-mata kerana Allah SWT dan tetap teguh dalam mentauhidkan-Nya; kedua, mematuhi segala syariat yang telah ditetapkan oleh Allah SWT dan dibawa oleh Rasulullah SAW, dengan penuh penghayatan dan pengamalannya; dan ketiga, sentiasa melakukan amalan kebaikan sama ada dalam berhubungan dengan Allah SWT atau berhubungan sesama manusia (Muhammad Syukri Salleh, 1993). Hal ini jelas berbeza dengan matlamat kepenggunaan konvensional yang hanya mementingkan keuntungan serta kesejahteraan dunia semata-mata.

\section{Kesimpulan}

Berdasarkan keseluruhan perbincangan dalam kajian ini, didapati model kepenggunaanwasatiyyah merupakan konsep kepenggunaan yang realistik dan komprehensif. Ia terdiri daripada tiga perkara. Pertama, tauhid sebagai falsafahnya; kedua, tahap kepenggunaanwasatiyyah yang berakar umbikan komponenkomponen maqasid al-syari 'ah iaitu daruriyyah, hajiyyah, tahsiniyyah, kamaliyyah, dan barang merbahaya atau merosakkan; dan ketiga, mencapai kebaikan dan keredaan Allah SWT sebagai matlamat kepenggunaan-wasatiyyah.

Pembinaan model kepenggunaan-wasatiyyah ini sangat siginifikan kerana ia dapat mengeluarkan umat Islam daripada terus mengamalkan kepenggunaan konvensional yang didominasi oleh sistem liberal-kapitalis. Pada masa yang sama ia dapat membantu masyarakat dalam mengurus kewangan mereka dengan baik iaitu berbelanja mengikut keutamaan dan kemampuan serta mengelak daripada sikap boros, membazir dan berbelanja untuk perkara yang tidak berfaedah. Amalan ini akan mewujudkan kestabilan kewangan dan keharmonian dalam kehidupan bagi seseorang individu, keluarga, masyarakat ataupun negara.

Selain itu, penggunaan dalam bentuk hutang yang dibuat berdasarkan model kepenggunaanwasatiyyah juga akan menghasilkan hutang yang baik iaitu hutang yang dapat memberi manfaat dan mendatangkan hasil yang boleh membawa kepada kesejahteraan kehidupan seperti hutang yang digunakan untuk tujuan pendidikan atau perniagaan. Sebaliknya, hutang yang tidak berteraskan prinsip maqasid alsyari 'ah ini akan menghasilkan hutang yang tidak baik iaitu hutang yang membebankan. Akhirnya ia memerangkap seseorang itu dalam krisis kewangan sehingga menjadi muflis.

Islam memberikan kebebasan kepada manusia untuk menikmati kehidupan yang wajar dan selesa. Meskipun diberi kebebasan, Islam tidak membenarkan umatnya mengguna semata-mata untuk membeli barangan yang mewah dan tidak perlu serta melampaui batas. Oleh itu, hutang yang dilakukan hendaklah mengutamakan susunan sebagaimana yang digariskan dalam ilmu maqasid al-syari 'ah iaitu dimulai dengan daruriyyah, kemudian diikuti dengan hajiyyah, tahsiniyyah, kamaliyyah, dan barang merbahaya atau merosakkan Jika maqasid al-syari'ah diabaikan dalam penggunaan terutamanya hutang, maka akan timbul kepincangan dalam kehidupan terutama dari segi aspek ekonomi dan sosial seperti berlakunya kes muflis dan bankrap.

Meskipun banyak perkara diinginkan dalam kehidupan, namun kita haruslah bijak mengurus kewangan harian dengan membezakan antara berhutang untuk keperluan dengan berhutang untuk kemahuan. Hal ini akan mengelakkan seseorang itu daripada bersifat boros yang boleh mengundang masalah kewangan yang serius 
kepada si penghutang.

\section{Penghargaan}

Makalah ini adalah sebahagian daripada hasil kajian yang berjudul Pembinaan Model Kepenggunaan-Wasatiyyah (203. CISDEV.6711588) yang dibiayai oleh Skim Geran Penyelidikan Fundamental (FRGS), Fasa 1/2017, Universiti Sains Malaysia, Pulau Pinang, Malaysia.

\section{Rujukan}

Abdul Aziz Sahidin, Azizah M. Isa, Mohd Shukor Abdul Manan \& Habibah Lehar (2000). Teori penggunaan menurut perspektif Islam, in. Ghafarullahhuddin Din et. al. (eds.), Ekonomi Islam. Shah Alam, Selangor: Biroteks Universiti Teknologi MARA.

Abdul Halim Abd Kadir, Nor Azzah Kamri \& Baharom Kassim. (2013). Maqasid Syariah: Isu- isu kepenggunaan, realiti dan cabaran, in Abdul Karim Ali \& Mohd Nazri Chik (eds.), Maqasid Syariah isu-isu kepenggunaan: Realiti dan cabaran. Selangor: Persatuan Ulamak Malaysia.

Abdul Monir Yaacob. (2015). Manhaj wasatiyyah dalam pelaksanaan hukum di Malaysia, in Mohd Yusuf Din (eds.), Penghayatan wasatiyyah dalam kerangka maqasid syariah. Putrajaya: Institut Wasatiyyah Malaysia (IMW).

Abdullah Md. Zin. (2012). Pendekatan Wasatiyyah Dalam Menghayati 1 Malaysia. Kuala Lumpur: Kasturi Jingga Corporation Sdn. Bhd.

Abdullah Md. Zin. (2013). Pendekatan Wasatiyyah: Definisi, Konsep dan Pelaksanaan. Putrajaya: Institut Wasatiyyah Malaysia (IMW).

Abdullah Md. Zin. (2014). Penghayatan Wasatiyyah Dalam Pentadbiran Malaysia. Putrajaya: Institut Wasatiyyah Malaysia
(IMW).

Afzal-ur-Rahman. (1974). Economic doctrine of Islam. Vol. 2. Lahore, Pakistan: Islamic

Publication Ltd.

Al-'Alim, Yusuf Hamid. (1997). Al-Maqasid al-syari 'at al-Islamiyyat. Al-Khartum: Dar alSudaniyyat.

Aleya Amri. (2016). 68 Peratus Rakyat Malaysia Hutang Tinggi. Retrieved July 20, 2016, from https://www.google.com.my/ node 130350/amp.

Al-Fayruz Abadi, Muhammad Ibn Ya'qub alFayruz Abadi. (1997). Al-Qamus al-Muhit. Beirut, Lubnan: Dar al-Kutub al'Alamiyyah.

Ali Muhammad al-Salabiy. (1999). AlWasatiyyah fi al-Qur'an al-Karim. 'Amman, Jordan: Dar al-Nafa'is.

Al-Qaradawi, Yusuf. (1995). Al-hayah alrabbaniyyah wa al-'ilm. Kaherah, Mesir: Maktabah Wahbah.

Al-Qaradawi, Yusuf. (2000). Kemiskinan dan cara Islam mengatasinya (Musykilat alFiqr wa kayfa 'alijuha al-Islam), terj. Arsil Ibrahim. Kuala Lumpur: Yayasan Pembangunan Ekonomi Islam Malaysia (YPEIM).Al-Raysuni, Ahmad. (1996). Nazariyyat al-maqasid 'inda al-Imam al-Syatibiy. Riyad: Dar al-'Alamiyyat li al-Kitab al-Islamiy.

Al-Syatibi. (t.t). Al-Muwafaqat fi usul al-ahkam. Beirut: Dar al-Ma'rifah.

Basri Abd. Ghani, Abd Aziz Harjin \& Sayuti Abd. Ghani (2008). Konsep Penggunaan dari Perspektif Ekonomi Islam. Paper presented at Seminar Keusahawanan Islam II Peringkat Kebangsaan 2008, organised by 
Akademi Pengajian Islam Universiti Malaya, 15 Oktober 2008.

Biraima, M.E. (1991). Qur'anic model for a universal economic theory. JKAU: Islamic Econ., Vol. 3, p. 3-41 (1411 A.H./1991 A.D.

Bontrup, H.J. (1998). Volkswirtschaftslehre. Munich, Germany: R. Oldenbourg Verlag.

Carroll, P. (2009). Articulating theories of states and state formation. Journal of Historical Sociology, Vol. 22, Issue 4, December 2009, p. 553-603

Chandra Muzaffar. (2011). Prinsip Wasatiyyah Jadi Teras Gagasan 1Malaysia: Masyarakat Majmuk Perlu diberi Kesedaran Mengenai Kepentingan, Keadilan, Keseimbangan. Dipetik pada 14 Disember 2016. Dipetik dari http:// www.bharian.com.my /articles/

Fadhilah Mat Nor, Aza Shahnaz Azman, Mawar Murni Yusnos \& Abdul Ghafar Ismail (2016). Epistemologi Tauhid Dalam Pemikiran Ekonomi: Teori Penggunaan. Paper presented at International Conference on Aqidah, Dakwah \& Syariah (IRSYAD 2016), at Grand Blue Wave Hotel, Shah Alam, 10 May 2016.

Gailbraith, J.K. (1967). The New Industrial State. London, UK: Pelican Books.

Ghilman Nursidin. (2012). Konstruksi pemikiran maqāṣid al-syari 'at Imam al-Haramayn alJuwayniy (Kajian Sosio-Historis). Postgraduate thesis, Institut Agama Islam Negeri (IAIN) Walisongo, Semarangan, Indonesia. Unpublished.

Hal R. Varian, H.R. (1996). What use is economic theory? in Steven Medema (ed.), Foundations of Research in Economics: How do Economists Do Eco-nomics?. United Kingdom: Edward Elgar.

Heilbroner, R.L. (1962). The Making of Economic Society. Englewood Cliffs, New
Jersey, USA: Prentice-Hall.

Hishamuddin Rais. (2016). Pembaziran Makanan di Malaysia Sangat Tinggi. Retrieved July 20, 2016, from http://m.utusan.com. $\mathrm{my} /$ bisnes/ekonomi/rakyat-malaysia-palingramai- berhutang-1.196814.

Ibn Manzur, Abi al-Fadl Jamal al-Din Muhammad bin Mukram al-Afriqiy al-Misriy. (1993). Lisan Al-'Arab. Jld. 11. Beirut, Lubnan: Maktabah Tahqiq Al-Turath.

Ismail Al-Hasani. (1995). Nazariyyat almaqasid 'inda al-Imam Muhammad al-Tahir Ibn al- 'Asyur. Virginia: International Institute of Islamic Thought.

Ismail Ibrahim. (2012). Wasatiyyah dan Masyarakat Pelbagai Kaum di Malaysia, in Muhammad Mustaqim Mohd Zarif (ed.), Islam dan Wasatiyyah. Nilai, Negeri Sembilan: Universiti Sains Islam Malaysia.

Jon Hanson (2005). Good debt, bad debt: Knowing the difference can save your financial life. New York: Penguin Group.

Kahf, M. (1989). "Islamic economics system :A review", in Aidit Ghazali \& Syed Omar (eds.), Reading concept and methodology ofislamic economics. Petaling Jaya: Pelanduk Publications.

Kahf, M. (1992a). A Contribution to the Theory of Consumer Behaviour in an Islamic Society. Studies in Islamic Economic, International Centre for Research in Islamic Economics KAAU, Jeddah, p. 19-36

Kahf, M. (1992b). The Theory of Consumption, in Sayyid Tahir et. al. (eds), Readings in Microeconomics: An Islamic Pespective. Petaling Jaya, Selangor: Longman Malaysia Sdn. Bhd. 
Khader Ahmad, Mohd Farhan Md Ariffin, Mohd Khairi Shafie, Sedek Ariffin, Fauzi Deraman \& Mustafa Abdullah. (2016). Penekanan aspek wasatiyyat bagi pembangunan kesejahteraan masyarakat Islam melalui pengubatan alternatif Islam: pengalaman di Malaysia. Retrieved October 26, 2016, from http://www.academia. edu/21494290/.

Khalijah Mohd Salleh. (2011). "Sains tauhidik \& implikasi terhadap pendidikan", in Khalijah Mohd Salleh (ed.), Pendidikan sains berteraskan tauhid. Bangi, Selangor: Institut Islam Hadhari, Universiti Kebangsaan Malaysia (UKM).

Khan, M. F. (1992). Thoery of consumer behaviour in an Islamic theory of consumer, in Readings in Microeconomics: An Islamic Pespective. Petaling Jaya, Selangor: Longman Malaysia Sdn. Bhd.

Khurshid Ahmad. (1980). "Economic development in an Islamic framework", in Khurshid Ahmad et al. (eds.), Studies in Islamic economic. Jeddah: International Centre for Research in Islamic Economics King Abdul Aziz University, Jeddah \& The Islamic Foundation, United Kingdom.

Mahmud Abdul Rahman. (2015). Wasatiyyah di Arab Saudi: manhaj dan pelaksanaan, in Mohd Yusuf Din (ed.), Penghayatan Wasatiyyah Dalam Kerangka Maqasid Syariah. Putrajaya:Institut Wasatiyyah Malaysia.

Marshall, A. (1890). Principles of economics. London: Macmillan and Co.

Meadows, E. (1977). "The New and Improved Consumer Behavior Theory", Studies in

Economics and Finance, Vol. 1 Issue 1, p.1627, https://doi.org/10.1108/eb028586

Mohammad Aizat Jamaludin, Mohd Anuar Ramli, Mariam Abdul Latif \& Dzulkifly Mat Hashim Suhaimi Ab Rahman (2012). Pendidikan kepenggunaan halal di Malaysia, in. Norarfan Zainal et al. (eds.), Membongkar Rahsia Pendidikan Islam. Bandar Seri Begawan: Kolej Universiti Perguruan Ugama Seri Begawan, p. 285-289.

Mohd Anuar Ramli \& Mohammad Aizat Jamaludin. (2012). Pengenalan kepenggunaan Islam. Retrieved December 15, 2013, from http://www.academia.edu/4350011/

Pengenalan_kepenggunaan_Islam.

Mohd Najib Abdul Razak. (2015a). Memartabatkan Wasatiyyah. Putrajaya: Institut Wasatiyyah Malaysia (IMW).

Mohd Najib Abdul Razak. (2015b). Pelaksanaan Menyeluruh Wasatiyyah. Putrajaya: Institut Wasatiyyah Malaysia (IMW).

Mohd Ridhuan Tee Abdullah. (2012). Memahami wasatiyyah, in Koleksi artikel pilihan sempena Seminar Pemahaman Wasatiyyah dan 1Malaysia. Kuala Lumpur: Sekretariat Seminar Pemahaman Wasatiyyah dan 1Malaysia.

Mohd Shukri Hanapi. (2014). Tasawur Islam dan Pembangunan. Kuala Lumpur: Dewan Bahasa dan Pustaka.

Muhammad Syukri Salleh (2013). 7 Prinsip Pembangunan Berteraskan Islam. Kuala Lumpur: Zebra Editions Sdn. Bhd.

Muhammad Syukri Salleh. (2003). Tujuh prinsip pembangunan berteraskan Islam. Kuala

Lumpur: Zebra Edition Sdn. Bhd.

Noor Ashikin Hamid, Nur Amani Pauzai \& Shariffah Nuridah Aisyah Syed Nong (2011). Konsep Kepenggunaan Mengikut Syariah dan Aplikasinya Dalam Undang-Undang Malaysia. Jurnal Kanun Undang-undang Malaysia, Vol.1, June 2011, Universiti Darul Iman Malaysia, Terengganu.

Norliza Abdul Wahid. (2011). Penggunaan dalam konteks ekonomi islam dan perbandingan 
dengan ekonomi konvensional. Project paper Faculty of Economics and Administration.

Kuala Lumpur: Universiti Malaya.

Nur Nazlina Nadzari. (2016). Rakyat Malaysia paling ramai berhutang. Retrieved July 20, 2016, from http://www.mstar.com.my/lainlain/rencana/2016/05/30/pembaziran-makanan/.

Nurshuhaida Abdul Razak \& Siti Zaiton Mohd Dali. (2012). Perbezaan analisis kepenggunaan menurut ekonomi konvensional dan ekonomi Islam. Paper presented at Persidangan Kebangs a a n Ekonomi Malaysia ke-VII (PERKEM VII), Ipoh, Perak, 4-6 Jun 2012.

Pollak, R.A. (1969). Conditional Demand Functions and Consumption Theory, The Quarterly Journal of Economics, 1969, Vol. 83, Issue 1, p. 60-78.

Raiklin, E., \& Uyar, B. (1962). On the Relativity of the Concepts of Needs, Wants, Scarcity and Opportunity Cost. International Journal of Social Economics, 23(7), 49-56.

Sardar, Z. (1990). Masa Hadapan Islam (Islamic Future: The Shape of Ideas to Come), translated by Mohd Siden Ahmad Ishak. Kuala Lumpur: Dewan Bahasa dan Pustaka (DBP).

Siddiqi, M.N. (1992). Islamic Consumer Behaviour, in Readings in Microeconomics: An Islamic Pespective. Petaling Jaya, Selangor: Longman Malaysia Sdn. Bhd.

Surtahman Kastin Hasan. (2011). Ekonomi Islam Pengenalan. Selangor: Universiti Kebangsaan Malaysia.

Syaidatana Siti Aishah Ab Aziz. (2014). Konsep Wasatiyyah Dalam Gagasan 1Malaysia:

Analisis Berdasarkan Tafsiran Ayat 143 Surah Al-Baqarah. Master Dissertation (M.Soc Islamic Development Management), Centre for Islamic Development Management
(ISDEV), Universiti Sains Malaysia, Penang. Unpublished.

Syed Omar Syed Agil (1992). Rationality in Economic Theory, in Readings in Microeconomics: An Islamic Pespective. Petaling Jaya, Selangor: Longman Malaysia Sdn. Bhd.

Wan Kamal Mujani, Ermy Azziaty Rozali \& Nor Jamaniah Zakaria. (2015). The wasatiyyat (moderation) concept: Its implementation in Malaysia. Mediterranean Journal of Social Sciences, 6(4), 66.

Weber, M. (1958). From Max Weber: Essays in sociology. New York : Oxford University Press.

Zaharuddin Abd Rahman. (2014). Fiqh kewangan Islam: halal dan haram dalam sistem jual beli Islam. Selangor: PTS Islamika Sdn. Bhd.

Zulkifli Mohamad al-Bakri. (2011). Wasatiyyah Konsep dan Pelaksanaan. Kuala Lumpur: Yayasan Dakwah Islamiah Malaysia.

Zulkifli Mohamad al-Bakri. (2014). Maqasid al-Syari'at: Satu Pengenalan Umum. Negeri Sembilan: Pustaka Cahaya Kasturi. 
